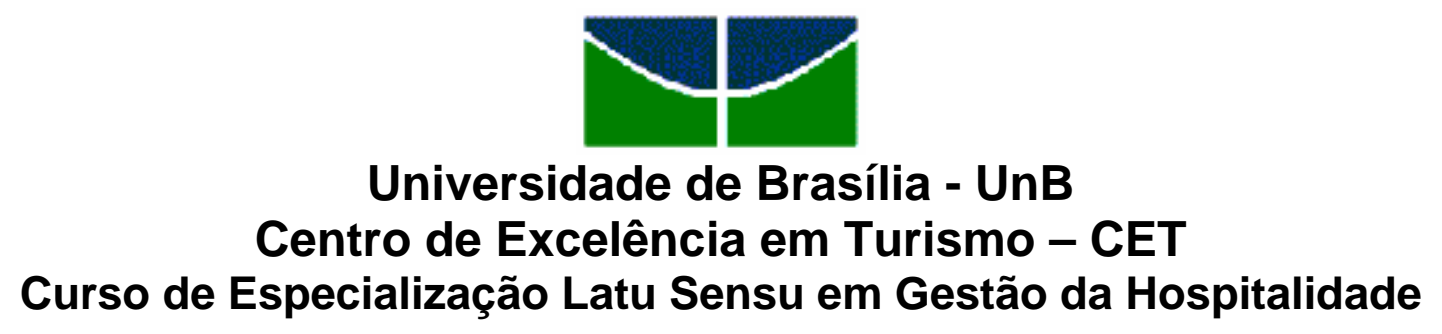

\title{
A importância da comunicação interpessoal para a hotelaria
}

Carlos Wendell Queiroz de Souza

Brasília, DF,

Novembro, 2003 


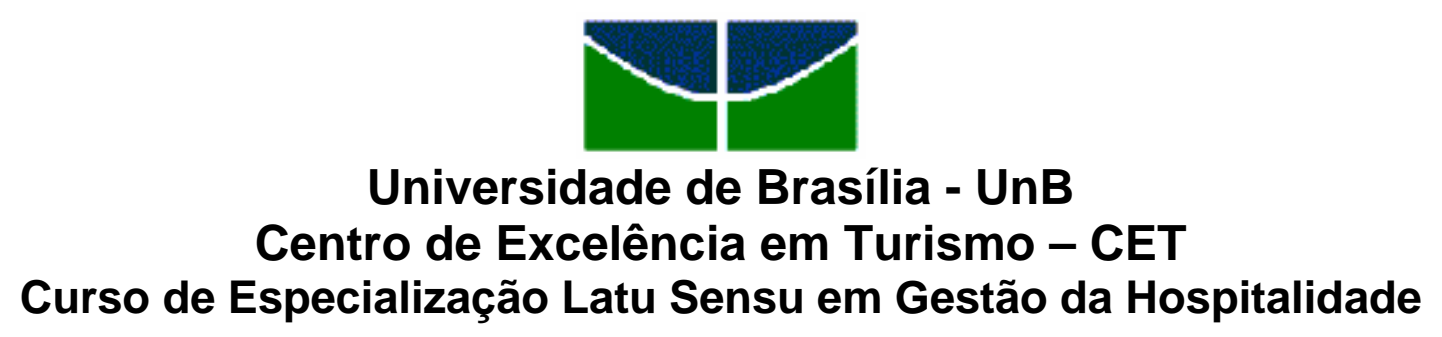

\section{A importância da comunicação interpessoal para a hotelaria}

Carlos Wendell Queiroz de Souza

Orientador: Prof. Dr. José Parente Filho

Monografia apresentada ao Centro de Excelência em Turismo - CET, da Universidade de Brasília - UnB, como requisito parcial para a obtenção do título de Especialista em Gestão da Hospitalidade.

Brasília, DF,

Novembro, 2003 
Souza, Carlos Wendell Queiroz de
A importância da comunicação

A importância da comunicação interpessoal para a hotelaria I Carlos Wendell Queiroz de Souza. $49 f$.

Monografia (Especialização) - Universidade de Brasília, Centro de Excelência em Turismo, Curso de Especialização Latu Sensu em Gestão da Hospitalidade, 2003.

Orientador: José Parente Filho

1. Comunicação 2. Comunicação Interpessoal 3. Hotelaria 


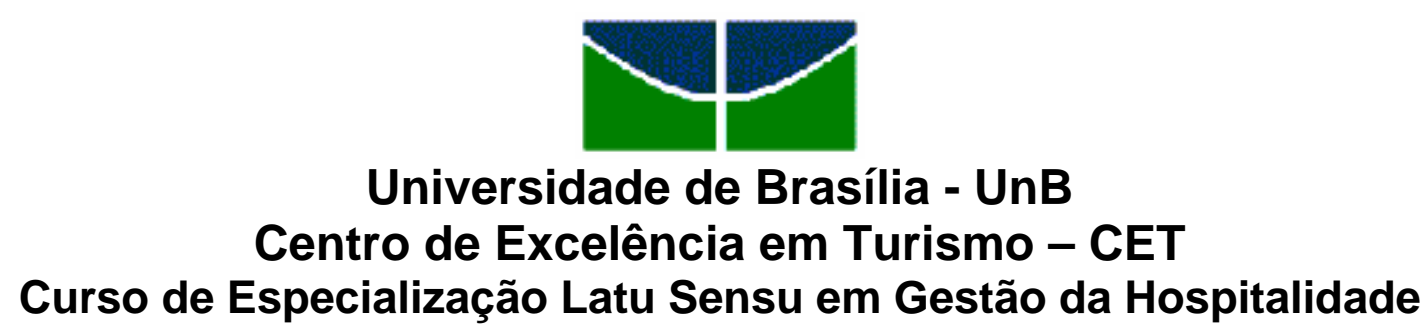

\section{A importância da comunicação interpessoal para a hotelaria}

Carlos Wendell Queiroz de Souza

Banca Examinadora

\begin{tabular}{c}
\hline $\begin{array}{c}\text { José Parente Filho } \\
\text { (Orientador) }\end{array}$ \\
\hline (Membro da Banca)
\end{tabular}

Brasília, DF,

Novembro, 2003 
"A comunicação começa com os pensamentos, que comunicamos aos outros usando palavras, o tom de voz e a linguagem corporal. Mas o que são pensamentos? Existem muitas respostas científicas diferentes; entretanto, todo mundo conhece no seu íntimo o que o pensamento é para si próprio. Uma maneira de entender o que é o pensamento, é perceber que estamos usando nossos sentidos internamente." 


\section{Dedicatória}

Dedico este trabalho a meus pais, que nunca mediram esforços para que eu pudesse ter uma boa educação. A minhas irmãs que sempre me apoiaram e também a minha noiva que estão comigo nesta jornada. 


\section{Agradecimentos}

Agradeço ao mestre José Parente Filho por sua generosidade, pelo exemplo de comunicador e, acima de tudo, pelo apoio indispensável, no momento de decisão e orientação do tema aqui exposto.

A você, Maurício Alves Rezende, amigo-hospitaleiro, meu carinho e admiração, SEMPRE!

A Jacirema, minha eterna gratidão pela oportunidade a mim confiada. Você, também, faz parte desta conquista!

A Roberto pelo exemplo de disciplina, a Jurema pelo carinho e suporte, e a Sabrina pela compreensão. Agradeço, principalmente, a confiança e a oportunidade de convivência com vocês!

Nayane e Nyvea, irmãs-amigas, as suas conquistas me orgulham e me encorajam a seguir, confiante na vitória de meus desafios!

Aos meus amados pais, Flaudomir e Gláucia, por acreditarem em mim, antes que eu o fizesse. A vocês, tenho muito a agradecer: o amor incondicional, o carinho, o apoio, os perdões, os exemplos de honestidade e persistência e a coragem. Amo muito vocês!!!

Por fim, a minha noiva, Karina, meu grande amor, agradeço sua paciência e companheirismo, durante todo o curso! Seus conhecimentos em psicologia foram de fundamental importância, neste trabalho e me ajudaram a entender sua escolha profissional. É impossível descrever o orgulho que sinto de estar com você! Te amo... 


\section{Resumo}

A comunicação não é somente um recurso de relacionamento utilizado por todos os seres viventes, mas é uma ferramenta de trabalho fundamental para a consecução de qualquer tarefa de que se pretenda realizar. $O$ relacionamento entre as pessoas é facilitado por meio da comunicação, ainda mais dentro de um ramo de atividade que cresce constantemente a cada dia como é o caso do setor de hotelaria. Dinâmico e flexível, este é o perfil de quem pretende atuar neste ramo de atividade econômica, de maneira que para a hotelaria a comunicação interpessoal revela-se como ferramenta capaz de auxiliar no atendimento, prestação de serviços e motivação do pessoal envolvido no mesmo. Neste estudo, percebemos o quanto é importante a comunicação interpessoal para a concretização e fortalecimento para as relações hoteleiras.

PALAVRAS -CHAVE: Comunicação; Comunicação Interpessoal; Hotelaria. 


\section{Abstract}

The communication is not only a resource of relationship used for all the living beings, but it is a tool of basic work for the achievement of any task of that if it intends to carry through. The relationship between the people is facilitated by means of the communication, still more inside of an activity branch that grows constantly to each day as it is the case of the sector of would hotelaria. Dynamic and flexible, this is the profile of who intends to act in this branch of economic activity, thus for the interpersonal communication would hotelaria shows as tool capable to assist in the attendance, rendering of services and motivation of the involved staff in exactly. In this study, we perceive how much it is important the interpersonal communication for the concretion and fortalecimento for the hoteleiras relations.

KEY WORDS: Communication; Interpersonal communication; Hotelaria. 


\section{Sumário}

RESUMO

ABSTRACT

INTRODUÇÃO …........................................................................................... 09

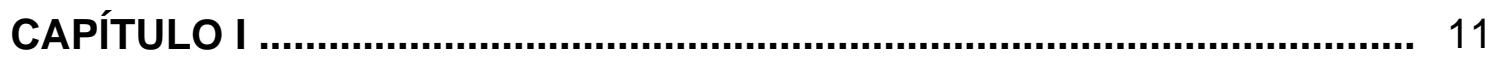

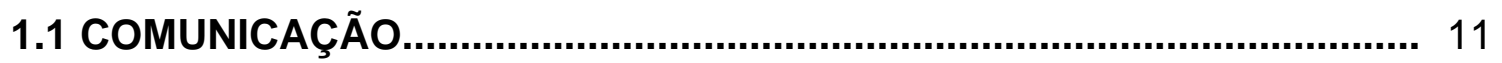

1.2 PROCESSO BÁSICO DE COMUNICAÇÃO.......................................... 13

1.3 COMUNICAÇÃO NO TERCEIRO MILÊNIO.......................................... 16

1.4 COMUNICAÇÃO NAS ORGANIZAÇÕES............................................ 17

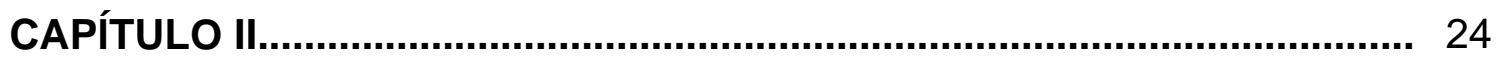

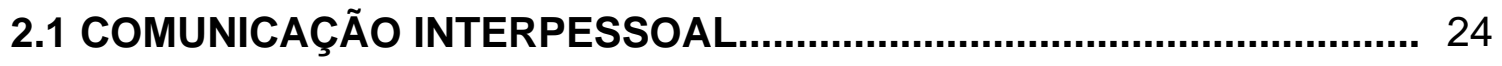

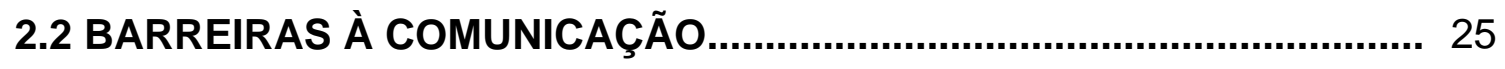

2.3 COMO MELHORAR A COMUNICAÇÃO EFICAZ.................................. 26

2.4 A ARTE DA COMUNICAÇÃO INTERPESSOAL.................................. 27

2.5 COMUNICAÇÃO INTERPESSOAL: FUNDAMENTAL PARA

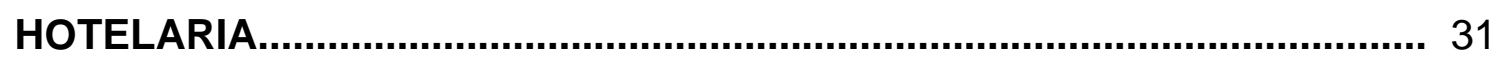

2.6 HABILIDADES DA COMUNICAÇÃO INTERPESSOAL PARA

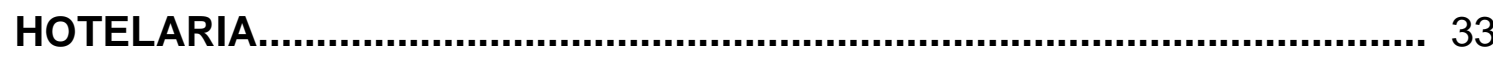

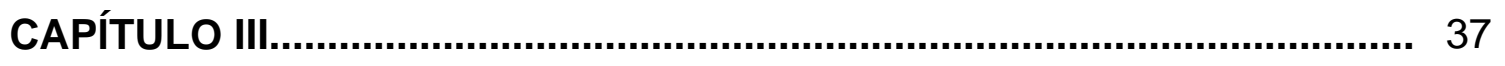

3.1 TURISMO NA ERA DA GLOBALIZAÇÃO.......................................... 37

3.2 ADMINISTRAÇÃO HOTELEIRA..................................................... 38

3.3 BREVE HISTÓRIA DOS MEIOS DE HOSPEDAGEM.............................. 39

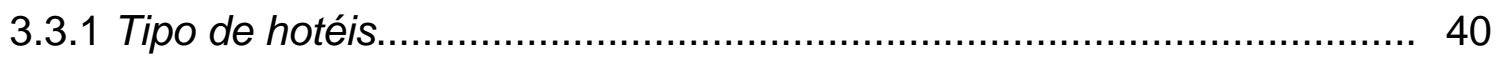

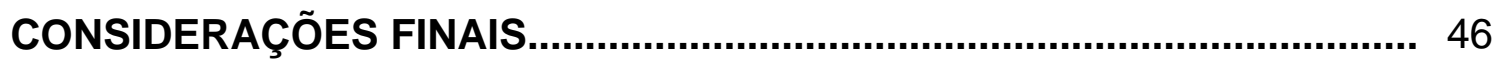

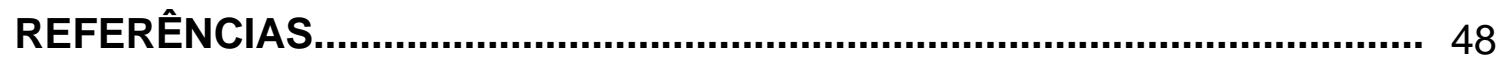




\section{INTRODUÇÃO}

As empresas da atualidade estão conscientes da importância do cliente e procuram atingi-lo e promovendo seu encantamento como forma para mantê-lo interessado por seus produtos ou serviços oferecidos. Além de produzir um produto ou serviço de boa qualidade, será necessário um acompanhamento do mesmo e de seu respectivo consumidor.

Conforme Brocka (1994) considera que a satisfação do consumidor é o melhor indicador dos lucros futuros de uma companhia.

Gerenciar as pessoas, que trabalham e produzem produtos e serviços para os outros, é muito difícil. O caminho para atingir a satisfação do cliente, seja em que ramo de atividade econômica tenhamos atuação, deve ser ponderado e conduzido pela comunicação. Ainda mais em um ramo tão dinâmico e heterogêneo quanto é o de hotelaria.

O desenvolvimento do turismo esta fortemente ligado à evolução do mercado hoteleiro, setor, entre outros, um dos mais importante para a expansão turística de um país ou estado.

É notório que cada vez mais os países que, dedicam-se ao turismo, como forma de auto-sustentação, buscam oferecer serviços que satisfaçam aos desejos dos seus visitantes, o que exige que se elabore um marketing praticamente impecável.

Ter a disposição toda uma infra-estrutura turística que beneficie o desenvolvimento e favoreça o crescimento econômico e social de uma região, e não dispor de pessoal preparado e capacitado para fazer com que esta infraestrutura funcione, é um risco grande de não se alcançar os objetivos esperados com os investimentos realizados.

Daí, entra em cena, como sendo peça de fundamental importância, a comunicação interpessoal como fator primordial para a gestão hoteleira. Este é o foco central do nosso objeto de estudo.

A comunicação interpessoal na hotelaria é fundamental por se tratar de um serviço, onde pessoas são levadas a interagir permanentemente. 
Os hóspedes interagem com mensageiros, recepcionistas, e manobristas, por exemplo. Todos os colaboradores da organização hoteleira procuram se comunicar da melhor forma possível com os seus clientes com o objetivo de prestar um bom serviço como forma de garantir tanto a qualidade do atendimento como, e por conseqüência, o retorno dos hóspedes, fator fundamental para a sustentabilidade do empreendimento. A boa gestão é indispensável. O bom gerenciamento é indispensável para garantir a satisfação do cliente e a sustentabilidade da organização. Ele busca usar da melhor forma possível os fatores produtivos, as competências, compreendendo aí comunicação interpessoal e a motivação do seu pessoal para o alcance dos fins da organização.

De acordo com a freqüência de utilização e com as tendências de mercado os três tipos mais comuns de hotéis são: o hotel convencional, o hotel resort e as pousadas. Em cada uma das categorias citadas a comunicação interpessoal adquire uma forma própria, indo de práticas mais formais, nos hotéis convencionais até maneiras mais familiares e informais entre clientes e trabalhadores das pousadas.

Neste estudo, o tema A IMPORTÂNCIA DA COMUNICAÇÃO INTERPESSOAL PARA A HOTELARIA está dividido em quatro capítulos:

No primeiro tratamos de fatores concernentes a comunicação como um todo, seus conceitos e reflexões acerca da mesma;

No segundo descrevemos aspectos voltados para a comunicação interpessoal, mais especifica de nosso objetivo de estudo;

No terceiro levantamos material teórico referentes a hotelaria e administração hoteleira como um todo;

Nas considerações finais, refletimos acerca do exposto anteriormente a fim de unificar os elementos apresentados isoladamente e que se entrelaçam, mostrando que a hotelaria necessita, fundamentalmente, da comunicação para a sua contínua expansão. 


\section{CAPÍTULO I}

\subsection{COMUNICAÇÃO}

Certos de que a comunicação é uma ferramenta que utilizamos para interagir com nosso meio, buscamos em Berlo (1999), Robbins (1987) e O'Connor e Seymour (1995) sustentação para embasar conceitos e definições que tragam à tona a revelação da importância deste recurso para a sociedade humana como um todo.

Entende-se por comunicação um laço ou ciclo que engloba no mínimo duas pessoas. Na comunicação uma ação provoca uma reação.

Reagimos de acordo com nossos sentimentos e pensamentos. $\mathrm{O}$ comportamento é gerado pelas representações mentais que temos.

Segundo Robbins (1987, p. 225): "Para nos comunicarmos efetivamente, devemos compreender que somos todos diferentes na maneira como vemos o mundo, e usar esse entendimento como guia para nossa comunicação com os outros".

$\mathrm{Na}$ comunicação a percepção até pode coincidir com a intenção pretendida, mas geralmente não é o que ocorre. Neste caso, há de se rever à mensagem e adotar novas estratégias de comunicação.

Comunicação não pressupõe apenas palavras escrita ou falada, compreende fundamentalmente outras partes de nossas capacidades de expressão como: Linguagem corporal (postura, gestos e contatos visuais). Contudo, se quisermos saber o significado da comunicação, devemos observar a reação obtida com os sinais que emitimos.

Quando nos comunicamos não é somente o que falamos, mas a maneira como falamos, também é muito representativa e significativa no processo de comunicação. Segundo O'Connor e Seymour (1995, p. 35): "as palavras são o conteúdo da mensagem, e a postura, os gestos, a expressão e o tom de voz são o contexto no qual a mensagem está embutida. Juntos eles formam o significado da comunicação." 
Ainda segundo estes autores, a comunicação corporal corresponde a $55 \%$ do total das formas como nos comunicamos, as palavras correspondem $7 \%$ e o tom de voz $38 \%$

\begin{abstract}
Usamos constantemente nossas habilidades de comunicação para influenciar pessoas. Qualquer procedimento de terapia, gerenciamento ou educação exige capacidade de influenciar e comunicar. Mas existe um paradoxo: Embora ninguém esteja interessado em aprender técnicas que não sejam eficientes pode ser rotulada como manipulação negativa de que algum modo se estaria forçando o outro a fazer algo que contraria seus interesses. Não é certamente o caso da PNL que é construída sobre profundos alicerces de sensatez, opções e ecologia. A PNL proporciona a capacidade de reagir de maneira eficaz aos outros e de compreender e respeitar seu modelo. (O'CONNOR E SEYMOUR, 1989, p. 35-36)
\end{abstract}

Nosso sucesso ou fracasso decorre daquilo que pensamos e o que fizermos com o que pensamos. Não basta simplesmente obtermos informações, elas são úteis e nos proporcionam maiores opções de escolhas. No entanto, a flexibilidade e a habilidade de agir são aspectos essencialmente importantes na obtenção de resultados e sucesso.

Se desejamos o sucesso é necessário que dominemos o movimento da comunicação. Entendermos que neste ciclo há uma causa e um efeito.

O que acontece conosco é determinado pela forma com que nos auto comunicamos e também da nossa comunicação com as outras pessoas. A qualidade dessa comunicação, implica na qualidade de vida que desejamos ter. Portanto, só podemos promover nossa qualidade de vida se em nossos mapas, tiver convicções ilimitadas fundamentadas em atitudes voltadas para resultados. Conforme Robbins (1987, p. 23):

Comunicação é poder. Aqueles que dominam seu uso efetivo podem mudar sua própria experiência do mundo e a experiência do mundo sobre si mesmos. Todo comportamento e sentimento encontram suas raízes originais em alguma forma de comunicação. Aqueles que afetam os pensamentos, sentimentos e ações da maioria de nós são aqueles que sabem com usar esse instrumento de poder. 


\subsection{PROCESSO BÁSICO DE COMUNICAÇÃO}

A comunicação humana, por ser complexa e fundamental, necessita que entendamos o seu processo básico, a fim de ter um conhecimento mais abrangente ao que concerne ao entendimento de suas relações entre emissor, receptor e feedback. Neste sentido no apoiamos em Shannon-Weaver, Berlo (1999), Batista (1971), Senge (1996) e Defleur e Ball-Rokeach (1996).

Para Senge (1996, p. 11): "uma mensagem pode ser transmitida de modo":

1. VERBAL - A comunicação verbal é o modo de comunicação mais familiar e mais freqüentemente usado. Divide-se em:

A) VERBAL-ORAL - Refere-se a esforços de comunicação tais como dar instruções a um colega, entrevistar um candidato a um emprego, informar alguma coisa a alguém, e assim por diante).

B) VERBAL-ESCRITA - Refere-se a memorandos, relatórios por escrito, normas e procedimentos.

2. SIMBÓLICA - As pessoas cercam-se de vários símbolos, os quais podem comunicar muito a outras pessoas. O lugar que moramos, as roupas que usamos, o carro que dirigimos, a decoração do escritório e outras coisas mais expressam parte da nossa personalidade (BERLO, 1999).

3. NÃO-VERBAL - A comunicação não-verbal, que se refere à transmissão de uma mensagem por algum meio diverso da fala e da escrita, é uma das facetas mais interessantes da comunicação. Incorpora coisas como o modo com que usamos o nosso corpo, os nossos gestos e nossa voz para transmitir certas mensagens.

Disso resulta que há maior ou menor exatidão daquilo que se quer transmitir. A exatidão na comunicação, por outro lado, se refere ao ponto até onde o sinal básico transmitido pelo emissor é recebido, sem distorções pelo receptor. 
Este processo se reflete no modelo de Shannon-Weaver, ilustrado na figura 1 , logo abaixo:

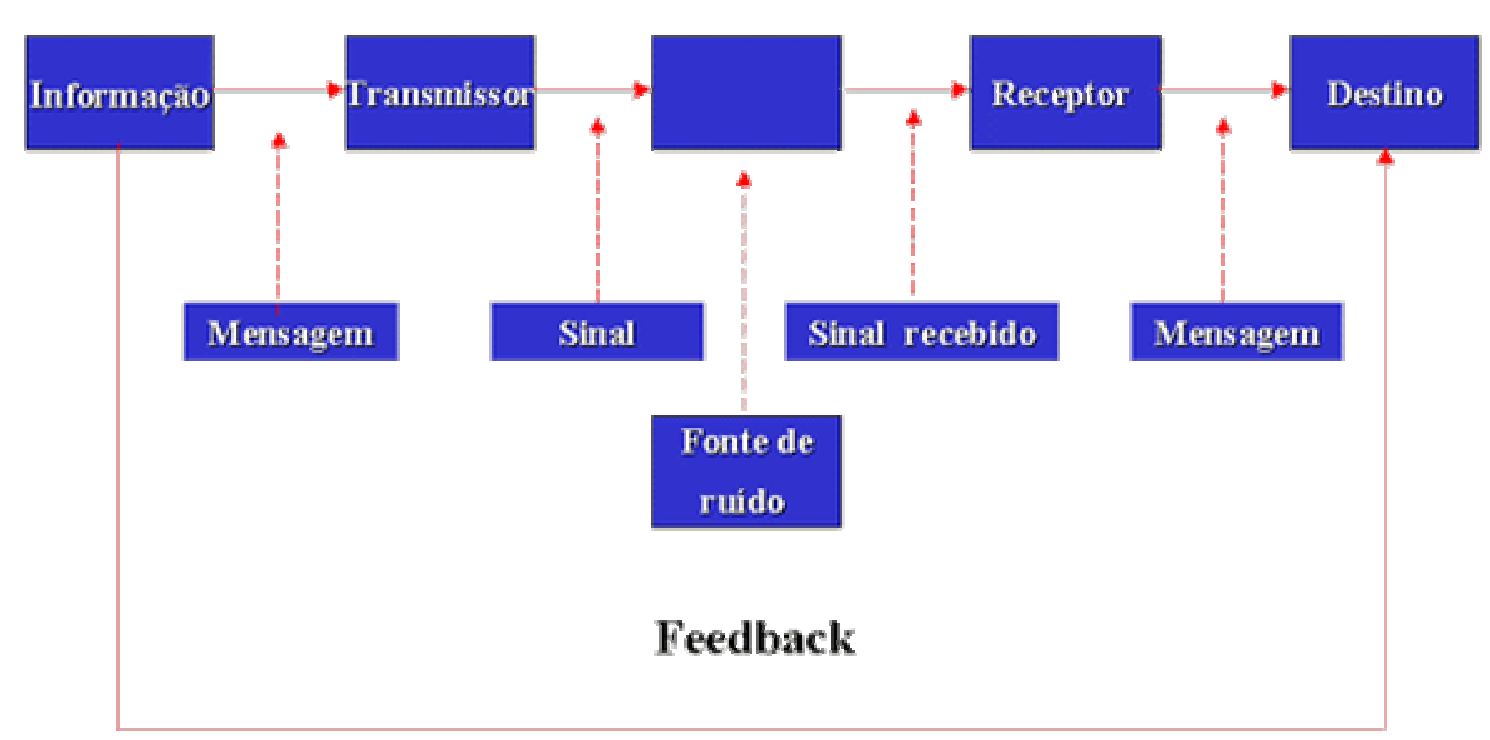

Fonte Adaptado de C. F. Shanone W. Weaver, The Whathenatued Theory of Comwancation.

Do lado do emissor há um processo de codificação; do lado do receptor, a decodificação. Entre a mensagem enviada e a recebida há um hiato, em que diversos ruídos podem aparecer, afetando a mensagem (DEFLEUR E BALL-ROKEACH, 1996).

Assim, a comunicação não estará completa enquanto o receptor não tiver interpretado (percebido) a mensagem. Se o ruído for demasiadamente forte em relação ao sinal, a mensagem não chegará ao seu destino, ou chegará distorcida.

Por ruído, entende-se tudo o que interfere na comunicação, prejudicando-a. Pode ser um som sem harmonia, um emissor ou receptor fora de sintonia, falta de empatia ou habilidade para colocar-se no lugar de terceiros, falta de atenção do receptor etc. 
Os recursos usados para anular ruídos são, de acordo com Batista (1971, p. 59):

a) redundância: é todo o elemento da mensagem que não traz nenhuma informação nova. É um recurso utilizado para chamar à atenção e eliminar possíveis ruídos. Nesse sentido, deve-se repetir frases e informações julgadas essenciais à compreensão do receptor;

b) feedback: conjunto de sinais perceptíveis que permitem conhecer o resultado da mensagem; é o processo de se dizer a uma pessoa como você se sente em função do que ela fez ou disse. Para isso, fazer perguntas e obter as respostas, a fim de verificar se a mensagem foi recebida ou não.

Como o simples ato de receber a mensagem não garante que o receptor vá interpretá-la corretamente (ou seja, como se pretendia), convém considerar, seguindo o pensamento de Senge (1996) que:

1. quem está comunicando a quem, em termos de papéis que essas pessoas desempenham (por exemplo, administração e operariado, gerente e subordinado).

2. a linguagem ou o(s) símbolo(s) usados para a comunicação, e a respectiva capacidade de levar a informação e esta ser entendida por ambas as partes.

3. o canal de comunicação, ou o meio empregado e como as informações são recebidas através dos diversos canais (tais como comunicação falada ou escrita).

4. o conteúdo da comunicação (boas ou más notícias, relevantes ou irrelevantes, familiares ou estranhas)

5. as características interpessoais do transmissor e as relações interpessoais entre transmissor e o receptor (em termos de confiança, influência etc.).

6. o contexto no qual o comunicação ocorre, em termos de estrutura organizacional (por exemplo, dentre de ou entre departamentos, níveis e assim por diante). 


\subsection{COMUNICAÇÃO NO TERCEIRO MILÊNIO}

É crescente a fascinação que percebemos nos indivíduos diante do desenvolvimento da informática no final do segundo milênio e início do terceiro.

Hoje, quando falamos em comunicação, temos disponíveis todos os recursos viabilizando a "otimização" da comunicação. Isso no que se refere a tecnologia. No local em que passamos a maior parte do tempo, que é o trabalho, nos comunicamos a todo instante através de uma máquina chamada computador, ou de um aparelho denominado telefone. Ainda temos a nosso dispor secretárias eletrônicas, voice mail, internet, fax entre outros.

Com esses meios de comunicação, aceleramos processos e com isso diminuímos a eficácia da comunicação, perdendo o foco da informação. No entanto ganhamos tempo para desenvolvermos outras atividades na correria do dia- a dia de trabalho (RUDIGER, 1995).

Contudo, no que concerne às relações humanas, percebemos o quanto elas se tornam mecânicas, estabelecendo vínculos "frios" na comunicação e conseqüentemente nos relacionamentos.

Para Schutz (1979, p. 34): "outro aspecto que podemos considerar como limitador nessas relações é a diminuição das possibilidades". São muitas as vezes que uma decisão se restringe a uma única possibilidade e nessa única vez, nos encontramos impossibilitados de sermos assertivos. Não disponibilizamos de tempo para negociações e nem deixam aflorar nossa flexibilidade.

O que permeia essa comunicação são pessoas com "pavios" mais curtos provocados pela ansiedade gerada pela necessidade de comunicação interpessoal direta, ou seja, da comunicação locutor interlocutor olhando olho no olho. O ser humano necessita de afeto, de carícias e o contato direto com outras pessoas propicia isso.

Percebemos um ambiente formado por contradições. De um lado nunca ouvimos tanto falar em trabalho em equipe $e$ habilidades de relacionamento interpessoal, como neste final de século. De outro lado há uma tendência forçada em tornar o ser humano cada vez mais isolado dos seus colegas, seja no trabalho, nas escolas e até mesmo nos contatos sociais. $\mathrm{O}$ advento da internet é uma ilustração disso. Pessoas mantém vínculos de 
amizades e até mesmo amoroso sem nunca terem estado frente à frente. Outra novidade são os cursos de pós-graduação à distância, onde o aluno assiste aulas via grupos que se encontram em salas virtuais com a orientação de um professor, ou através de videoconferências.

Aos contatos humanos, não estão sendo dadas a devida importância quanto, a qualidade e harmonia nos relacionamentos, por aqueles que interagem a relação. Dessa forma é que, as convivências encontradas num estado não desejado, nos levam às frustrações e descontentamentos.

De acordo com Rabaça e Barbosa (1998, p. 43): "não devemos no entanto, cruzar os braços e negligenciarmos as nossas relações". Cabe a cada um repensar a forma que quer se comunicar, lembrando sempre que é primordial para o ser humano o contato com seu semelhante, sendo que o sucesso ocorre da qualidade de relacionamentos que o indivíduo estabelece na esfera social, familiar e no trabalho.

Tendo em vista que nossas crenças e valores foram desenvolvidos por nós, cabe a nós mesmos repensá-los e se necessário reprogramá-los. Neste sentido cabe a pergunta: Estamos preparados ou nos preparando para novos desafios no que se refere a arte da comunicação? Se em nosso sistema de representação estamos nos colocando como vítimas, é hora de nos propormos mudar, fazendo reflexão sobre nossos objetivos. Vale saber que somos 100\% responsáveis pelo sucesso que desejamos.

\subsection{COMUNICAÇÃO NAS ORGANIZAÇÕES}

O estudo do processo de comunicação nas organizações tem sido alvo de formulações conceituais e modelos construídos a partir das teorias interacionistas de cunho sócio-psicológicas contingentes ao estudo das organizações como fenômenos sociais (RABAÇA; BARBOSA, 1998). Nessa perspectiva de análise é utilizado um recurso de decomposição do processo de comunicação para visualizá-lo como ação de reciprocidade intencional na qual o feedback assume importância central na avaliação de sua complexidade. 
Conforme Rudiger (1995, p. 34):

A complexidade no estudo dos processos de comunicação constitui um desafio ao diálogo e a pesquisa interdisciplinar, especialmente entre as chamadas ciências que discutem a natureza e a função da interação humana mediada por processo comunicacionais, como é o caso da sociologia, da psicologia, da antropologia e da lingüística.

Dessa forma, parece não ser possível separar os processos e as atividades comunicativas da compreensão do que seja a realidade das interações humanas, circunstanciadas em histórias de vida, vínculos e formas de relacionamento, processos de aprendizagem, enfim, nas relações com o ambiente mais próximo ou mais distante.

O processo de comunicação pode ser definido de uma forma mais simplificada como uma atividade humana caracterizada pela transmissão e recepção de informações entre pessoas ou, ainda, como o modo pelo qual se constróem e se decodificam significados a partir das trocas de informações geradas. (SCHUTZ, 1979).

A ação de comunicar pressupõe duas ou mais pessoas produzindo entre si um entendimento recíproco a partir de trocas simbólicas e pode ser definida, portanto, como um comportamento intencionalmente produzido que visa compartilhar uma determinada finalidade (explícita ou não), como já dissemos anteriormente. Esse comportamento intencional, conforme Wigand (1992), é expresso na forma de mensagens (verbais e não verbais) que são transmitidas entre um emissor e um receptor, levando este último a modificar o seu padrão de comportamento em resposta.

Dessa definição decorre um aspecto essencial: só há um processo de comunicação quando de alguma forma o conteúdo da mensagem é interpretado pelo receptor, ou seja, quando é observada uma resposta ao efeito da mensagem. Enviar uma carta ou deixar uma mensagem num gravador de chamadas não é comunicar, mas sim transmitir informação. Assim, "só haverá comunicação se, de alguma forma, o receptor indicar ao emissor que recebeu a informação que Ihe foi enviada, e isso só ocorre pelo envio de informação em retorno (feedback)" (FERREIRA, 1996, p. 176).

A sistematização do conhecimento sobre a comunicação humana foi iniciada há menos de um século, quando Harold Lasswell formula uma teoria da 
comunicação a partir da identificação dos componentes do ato comunicativo: emissor (es), receptor (es) e mensagem. Wiener, Westley e McLean são os responsáveis por introduzir um conceito importante para os estudos da comunicação, em particular da comunicação organizacional: a retroalimentação ou feedback, que aparece como mecanismo de controle (SKINNER, 1981).

Berlo (1999), no início dos anos 60, apresenta uma forte crítica à visão tradicional de que os significados estão nas palavras e símbolos e que comunicar consiste em transmitir idéias de um indivíduo a outro, como se o esquema F-M-C-R (fonte, mensagem, canal, receptor) funcionasse em uma direção vertical.

Berlo (1999) define comunicação como processo, marcado por relações dinâmicas, mutáveis e contínuas que, portanto, não permitem identificar uma fonte específica para determinada idéia ou mesmo afirmar que a comunicação se produza um único sentido. Segundo ele, o modelo clássico, ao ser transportado ao contexto das organizações, reproduz a separação dos papéis de comunicador e destinatário, como se ambos fossem seres isolados no processo.

A descrição clássica do processo de comunicação define um emissor ativo e um receptor passivo integrantes de um processo intencional que tem como objetivo persuadir através de seu conteúdo. Esse modelo clássico, centralizado no emissor e na relação estímulo-resposta, é perceptível no tratamento dado às comunicações nas organizações. Ele pode ser verificado na medida em que o processo de comunicação fica limitado à sua utilidade persuasiva, como se tivesse função de persuadir receptores (os trabalhadores, no caso) para integrá-los aos objetivos organizacionais, caracterizando-o como uma estratégia exclusivista e determinista do corpo diretivo das empresas.

Em torno dessa crítica, a linha de pesquisa de tradição norteamericana, conhecida como communication research, incorporou elementos que evidenciam a complexidade da relação emissor-mensagem-destinatário, marcando a inserção dos processos psicológicos intervenientes na recepção da mensagem.

Nessa perspectiva, é provável que a comunicação tenda a reforçar opiniões preexistentes e que pessoas se exponham à informação que estejam de acordo com as suas idéias e atitudes, rejeitando aquelas das quais discordam. 
Esse processo de exposição seletiva está vinculado ao tempo de exposição à mensagem e aos níveis de concordância com ela; assim, argumentos favoráveis tendem a ser memorizados em detrimento aos argumentos contrários nas mensagens.

A partir disso, propor uma análise dos processos de comunicação, tendo em vista os estudos sobre o comportamento humano em situações de interação social, significa assimilar um conceito que os comportamentalistas chamam de "comportamento social", definido por Skinner (1981), como o comportamento de duas ou mais pessoas em relação a uma outra em um ambiente comum. Assim, o comportamento social surge quando um organismo é importante para outro como parte do seu ambiente.

Baum (1999) afirma que é possível perceber o processo de comunicação como o comportamento de um organismo que gera estímulos que afetam o comportamento de outros organismos.

A partir do recurso de sistematização dos elementos constitutivos da definição de comportamento como uma relação significativa entre organismo e meio, proposto por Botomé (2001), é possível decompor o processo de comunicação (ação de comunicar) em uma relação de interação simbólica na qual pelo menos dois seres humanos enviam e recebem mensagens codificadas, ou seja, "tornam comum as coisas", em nível conceitual, através de símbolos.

O recurso proposto por Botomé (2001), que desmembra o comportamento em três momentos: a) situação anterior; b) ação humana e c) conseqüência ou situação decorrente, permite analisar, de forma comparada, os elementos constitutivos do agir comunicacional, o que significa decompor o processo de comunicação na situação em que ele é realizado. A decomposição possibilita uma maior visibilidade sobre o processo de comunicação como um comportamento intencionalmente produzido e expresso na forma de mensagens (verbais e não-verbais) construídos na interação entre as pessoas.

Dessa decomposição decorre um aspecto essencial: só há comunicação quando o emissor toma conhecimento de que o conteúdo da mensagem foi interpretado pelo receptor, ou seja, somente quando é observada uma resposta pelo envio de informação em retorno (feedback).

Desse modo, o processo de comunicação implica feedback sistêmico, ativado nas diferentes condições pelas quais se realizam as interações 
sociais. O efeito da comunicação pode ser aquele que é pretendido pelo emissor, e neste caso é possível afirmar que a comunicação é eficaz (JABLIN et al,1987 apud BERLO, 1999). Assim, só haverá comunicação se de alguma forma o receptor indicar ao emissor que recebeu a informação que lhe foi enviada, e isso só ocorre pelo envio de informação em retorno.

Como processo interativo de troca de mensagens simbólicas, 0 emissor age simultaneamente com o receptor e vice-versa. A mensagem compreende um conjunto de informações codificadas transmitidas por um canal, que pode ser definida como a intenção objetivada de transmitir um determinado significado. Assim, a transmissão da mensagem implica, por parte do emissor, uma codificação intencional de significado, e por parte do receptor, uma decodificação, ou uma nova atribuição de significado.

Essa análise está alicerçada na Escola de Chicago, que define a comunicação como um processo estruturado simbolicamente. Assim, "o processo de comunicação constitui o emprego de símbolos comuns com vistas á interação" (RÜDIGER, 1995, p. 33).

Nesse sentido, o significado das coisas deve ser entendido como um produto da interação social e como condição de possibilidade da comunicação. As pessoas agem em função do significado que as coisas adquirem no processo de comunicação e não em função das coisas propriamente ditas.

Do ponto de vista da interação social, o processo de comunicação é definido por Berger e Luckmann (1985), como processo de interação no qual os significados são apreendidos e compartilhados na reciprocidade de atos expressivos simultaneamente acessíveis aos seres da relação. Assim, a comunicação pode ser concebida como conjunto de comportamento seqüenciais e recorrentes na interação social, concentrando esforços na análise dos padrões de comportamento comunicativo (KRONE, JABLIN e PUTMAN, 1987 apud CURVELLO, 2001).

Essa interação consiste em um conjunto de comportamentos intencionais, inter-relacionados e específicos a uma dada situação que podem ser aprendidos (LITTLEJOHN, 1982). Na interação, busca-se dar significado aos símbolos. O significado não é transmitido entre o emissor e receptor, apenas a mensagem. Conseguir que a mensagem represente para o receptor um significado tão próximo quanto possível daquele que foi a intenção do emissor é 
objetivo da comunicação eficaz. Os significados atribuídos a uma mensagem dependem do modo de comunicação, das características pessoais do emissor e do receptor e do contexto da interação social.

Do ponto de vista simbólico, a comunicação é constituída por objetivações de significados, ou significações. A significação representa uma produção humana de significados materializados. Assim é possível afirmar que "os processos simbólicos são processos de significação" (BERGER e LUCKMANN, 1985, p.131). Dentre os processos de significação, a linguagem, definida como produção de sinais vocais, tem fundamental importância na construção de uma realidade social apreendida. É a partir daquela que o ser humano objetiva suas experiências. Como afirmam Berger e Luckmann (1985), vivemos em um mundo de sinais e símbolos e, na interação que estabelece com outros membros de sua coletividade, as pessoas constroem os seus repertórios de significados. Segundo Ferreira (1996), a existência de uma história no relacionamento com o receptor, ou o estado de desenvolvimento do relacionamento de um grupo, pode determinar a escolha de comportamentos comunicacionais em detrimento de outros.

A partir disso, é possível constatar que a comunicação é um processo sempre imperfeito, variando seu grau de eficácia de acordo com as variáveis que intervém na interpretação de significados. Assim, para garantir a eficácia do processo de comunicação, o grau de congruência entre as interpretações associado à mensagem enviada e recebida tem que ser elevado.

Com base nisso, Senge (1996, p. 25) afirma que "a existência de uma visão partilhada dos significados de uma mensagem é importante facilitador da interação social e, por conseguinte, da eficácia do comportamento organizacional".

No sentido de diminuir as probabilidades de desentendimento das mensagens recebidas, Kubo (2001) aponta cinco dificuldades que devem ser consideradas:

a) Conhecer as atitudes, crenças e sentimentos (estado mental) de outra pessoa;

b) Compreender que o estado mental depende de sinais freqüentemente ambíguos; 
c) Utilizar um sistema de codificação que decifre esses sinais;

d) Interpretar os comportamentos dos outros em função das circunstâncias na qual eles ocorrem;

e) Julgar o grau de correção acerca dos motivos e as atitudes dos outros em função da exatidão daquele que julga.

Nesse sentido, pode ser afirmado que um feedback eficaz, ou seja, dizer ao outro qual o efeito daquilo que se disse ou fez, é uma das formas de melhorar a comunicação interpessoal no contexto das organizações (MAFFESOLI, 1995).

Esta decomposição do processo de comunicação busca valorizar a possibilidade de adoção de uma perspectiva interacionista para pensar a comunicação nas organizações, dado que esse ponto de vista reforça a construção de significados como decorrência do processo de interação social. Em função disso, é possível analisar o processo de comunicação nas organizações a partir do conjunto de comportamentos intencionais da situação comunicativa. 


\section{CAPÍTULO II}

\subsection{COMUNICAÇÃO INTERPESSOAL}

Comunicação Interpessoal é essencialmente um processo interativo e didático (de pessoa a pessoa) em que o emissor constrói significados e desenvolve expectativas na mente do receptor.

A abordagem histórica dos médios constitui uma das formas para melhor se compreender o desenvolvimento da relação do homem com a COMUNICAÇãO. Partimos, assim duma seleção das principais invenções mediáticas no decurso dos tempos (do homo loquens e pictor ao "homo digital") para determinar os episódios marcantes do processo de comunicação (da comunicação interpessoal à comunicação virtual).

A história da comunicação segundo Cloutier (1975 apud CURVELLO, 2001) divide-se em comunicação interpessoal, de elite, de massa e individual e ainda um quinto episódio que começa a marcar o tempo actual: a comunicação em ambiente virtual.

Descreveremos a comunicação interpessoal, por esta ser a de interesse de nosso estudo e que se inicia quando o homem utiliza os meios apresentativos - os gestos e a voz - para se expressar. É muito difícil estabelecer com exatidão quando surgiu a primeira intenção de comunicação humana. Os primeiros sons do homem imitavam os rugidos gerados pelo ambiente, sons onomatopeicos.

O homo sapiens tornar-se-ia no homo loquens, inventando uma linguagem para exteriorizar as suas necessidades, as suas ideias e os seus desejos, diferenciando-se dos animais pela utilização de um sistema de comunicação progressivo e aberto que pode transmitir-se e enriquecer-se de geração em geração.

No período em questão não existiam ainda suportes materiais para a comunicação. A exteriorização pelo gesto e pela palavra necessita da presença de todos os interlocutores num mesmo espaço e momento (KUBO, 2001). 
O homem desenvolve a capacidade de produzir representações icónicas, dando origem ao homo pictor; fruto de uma habilidade intelectual e manual.

O homo pictor elabora técnicas e suportes diversos, embora utilize preferencialmente o muro das cavernas; no entanto existem réplicas simbólicas das cenas visuais do seu mundo circundante ou ideocenas presentes na sua imaginação. Esta comunicação simbólica pronunciava o advento da escrita dando origem à comunicação de elite.

\subsection{BARREIRAS À COMUNICAÇÃO EFICAZ}

Há diferentes formas de comunicar-se, como há também diferentes formas de comunicar-se de forma ineficiente. É o que ocorre com as barreiras que afetam a relação entre quem comunica e quem recebe uma dada informação. Neste sentido, Brocka (1995), Santos (1965), Bowditch (1992) entre outros, nos dá apoio para elencar algumas barreiras à comunicação eficaz:

1. Sobrecarga de Informações: quando temos mais informações do que somos capazes de ordenar e utilizar.

2. Tipos de informações: as informações que se encaixarem com o nosso autoconceito tendem a ser recebidas e aceitas muito mais prontamente do que dados que venham a contradizer o que já sabemos. Em muitos casos negamos aquelas que contrariam nossas crenças e valores.

3. Fonte de informações: como algumas pessoas contam com mais credibilidade do que outras (status), temos tendência a acreditar nessas pessoas e descontar de informações recebidas de outras.

4. Localização física: a localização física e a proximidade entre transmissor e receptor também influenciam a eficácia da comunicação. Resultados de pesquisas têm sugerido que a probabilidade de duas pessoas se comunicarem decresce proporcionalmente ao quadrado da distância entre elas.

5. Defensidade: uma das principais causas de muitas falhas de comunicação ocorre quando um ou mais dos participantes assume a defensiva. Indivíduos que se sintam ameaçados ou sob ataque tenderão a reagir de 
maneiras que diminuem a probabilidade de entendimento mútuo (BROCKA, 1995, SANTOS, 1965, BOWDITCH, 1992).

\subsection{COMO MELHORAR A COMUNICAÇÃO INTERPESSOAL}

\section{A) HABILIDADES DE TRANSMISSÃO}

1. Usar linguagem apropriada e direta (evitando o uso de jargão e termos eruditos quando palavras simples forem suficientes).

2. Fornecer informações tão claras e completas quanto for possível.

3. Usar canais múltiplos para estimular vários sentidos do receptor (audição, visão etc.).

4. Usar comunicação face a face sempre que for possível (BROCKA, 1995, SANTOS, 1965, BOWDITCH, 1992).

B) HABILIDADES AUDITIVAS

1. Escuta ativa. A chave para essa escuta ativa ou eficaz é a vontade e a capacidade de escutar a mensagem inteira (verbal, simbólica e nãoverbal), e responder apropriadamente ao conteúdo e à intenção (sentimentos, emoções etc.) da mensagem. Como administrador, é importante criar situações que ajudem as pessoas a falarem o que realmente querem dizer.

2. Empatia. A escuta ativa exige uma certa sensibilidade às pessoas com quem estamos tentando nos comunicar. Em sua essência, empatia significa colocar-se na posição ou situação da outra pessoa, num esforço para entendê-la.

3. Reflexão. Uma das formas de se aplicar a escuta ativa é reformular sempre a mensagem que tenha recebido. A chave é refletir sobre o que foi dito sem incluir um julgamento, apenas para testar o seu entendimento da mensagem.

4. Feedback. Como a comunicação eficaz é um processo de troca bidirecional, o uso de feedback é mais uma maneira de se reduzir falhas de comunicação e distorções (BROCKA, 1995, SANTOS, 1965, BOWDITCH, 1992). 
C) HABILIDADES DE FEEDBACK

1. Assegurar-se de que quer ajudar (e não se mostrar superior).

2. No caso de feedback negativo, vá direto ao assunto; começar uma discussão com questões periféricas e rodeios geralmente cria ansiedades ao invés de minimizá-las.

3. Descreva a situação de modo claro, evitando juízos de valor.

4. Concentre-se no problema (evite sobrecarregar o receptor com excesso de informações ou críticas).

5. Esteja preparado para receber feedback, visto que o seu comportamento pode estar contribuindo para o comportamento do receptor.

6. Ao encerrar o feedback, faça um resumo e reflita sobre a sessão, para que tanto você como o receptor estejam deixando a reunião com o mesmo entendimento sobre o que foi decidido (BROCKA, 1995, SANTOS, 1965, BOWDITCH, 1992).

\subsection{A ARTE DA COMUNICAÇÃO INTERPESSOAL}

Além das palavras, existe um mundo infinito de nuances e prismas diferentes que geram energias ou estímulos que são percebidos e recebidos pelo outro, através dos quais a comunicação se processa. Um olhar, um tom de voz um pouco diferente, um franzir de cenho, um levantar de sobrancelhas, podem comunicar é muito mais do que está contido em uma mensagem manifestada através das palavras (CURVELLO, 2001).

Uma dessas constatações de pessoas que se dizem com grandes problemas de comunicação é que, de fato, os problemas são relativamente simples e de fácil solução. O que ocorre é que esse problema, por menor que seja, compromete todo o sistema de comunicação. Por exemplo, uma pessoa pode ter boa cultura, ser extrovertida e desinibida, saber usar bem as mãos, possuir um rico vocabulário e dominar uma boa fluência verbal. Pode possuir tudo 
isso, mas se falar de forma linear, com voz monótona irá provocar desinteresse e sonolência aos ouvintes e, conseqüentemente, a comunicação ficou limitada.

O somatório desses pequenos problemas impede que uma pessoa se comunique com fluidez e naturalidade. É o mesmo princípio de que: "A união faz a força", ou seja, o conjunto dessas dificuldades neutraliza o efeito que a comunicação poderia provocar, impedindo-a de mostrar o seu potencial e a sua competência, gerando frustrações na vida pessoal e profissional.

$\mathrm{Na}$ arte da comunicação dentre os elementos que devem ser levados em consideração, destacam-se: a timidez, saber ouvir, corpo, vícios, prolixidade, controle emocional, foco de mudanças, motivação e auto-estima.

\section{a) Timidez}

Há pessoas que possuem muito conhecimento e muito talento mas na hora de falar em público, em uma reunião ou quando convidadas para proferir uma palestra, ficam totalmente apavoradas e preferem fugir a enfrentar. Se observarmos bem, uma pessoa não é valorizada por aquilo que sabe ou conhece, mas por aquilo que faz com aquilo que sabe. Por isso, a timidez tem impedido muitas pessoas de conseguirem galgar melhores possibilidades de sucesso na vida. Basicamente, os problemas de timidez manifestam-se por medos, tais como de não ser bem sucedido, de errar, de ter o famoso "branco".

Outra evidência é a baixa auto-estima, ou a sensação de incapacidade para se expressar diante de situações desafiadoras. Além disso, há o excesso de manifestações no próprio corpo, tais como tremedeira, gagueira, sudorese, taquicardia, chegando, em alguns casos até a desmaios.

\section{b) Saber ouvir}

Saber ouvir é muito mais do que escutar e darmos a nossa interpretação conforme desejarmos ou baseada nas nossas próprias limitações. Saber ouvir é cultivar a difícil arte da empatia que é a habilidade de se colocar no lugar do outro e prestar muita atenção no significado das palavras, na maneira em que a pessoa está transmitindo, no seu estado emocional, seus limites e 
conhecimentos; é olhar para os seus olhos, é perguntar se houver dúvidas, é evitar interpretar ou "alucinar" a partir do que foi dito (KUBO, 2001).

O mesmo princípio da empatia se processa para quem deseja se comunicar. Para conseguir um ótimo resultado, basta colocar-se no lugar do outro e gerar estímulos adequados conforme o jeito do outro funcionar, de processar informações, de entender conforme o seu nível cultural ou limitações de vocabulário, conceitos e experiências pessoais. A pergunta ideal para termos a evidência se, de fato, o outro entendeu o que dissemos é "O que você entendeu do que eu disse?". O mundo seria, certamente, bem melhor e as pessoas conseguissem relacionar-se melhor se pudessem fazer e responder a essa pergunta (SENGE, 1996).

Outra grande dificuldade para muitos (e o problema é que desses, poucos sabem) é sobre a utilização adequada da voz. Há pessoas que falam muito devagar, outras ainda que tem dicção ruim ou falam de forma linear ou ainda com volume muito baixo.

A questão é simples: como posso esperar, de fato, que alguém me compreenda ou preste atenção no que digo se nem sequer consigo entender o que estou dizendo?

\section{c) Corpo}

Curiosamente, a expressão corporal assume até mais importância do que a voz e, em alguns casos, do que o próprio conteúdo. Medo de olhar nos olhos, expressão facial incongruente com o conteúdo, aparência mal cuidada, ausência de gestos ou excessiva gesticulação, bem como posturas inadequadas são suficientes para tirarem o brilho de um processo de comunicação (BOWDITCH, 1992; MAFFESOLI, 1995).

\section{d) Vícios}

Quantas vezes ouvimos, ou melhor, tentamos ouvir pessoas, acompanhar seu raciocínio, mas fica difícil pois ouvimos alguns ruídos, tais como "aaaa...", "éééé....", "tá", "né", "certo", "percebe" repetidos inúmeras vezes. 
Deixamos de prestar atenção no conteúdo e ficamos incomodados com esses sons que dificultam a compreensão (BERLO, 1999).

\section{e) Prolixidade}

Por acaso, você conhece pessoas que dão várias voltas, entram em paralelas ou transversais, fazem retornos, dão marcha ré, engatam novamente a primeira marcha... Já deu para perceber que estamos falando de pessoas prolixas, ou seja: ninguém agüenta por muito tempo ouvir aquelas pessoas que falam demais e desnecessariamente, principalmente sobre assuntos sem interesse (RUDIGER, 1995; SANTOS, 1965).

\section{f) Controle Emocional}

Você já ficou magoado e ficou chateado um dia inteiro por um simples fato ocorrido no trânsito ou um tom de voz mais elevado em um momento de discussão ou um "bom dia" que não Ihe disseram? Você já imaginou o poder que você mesmo dá, assim, de presente a uma pessoa que você nem conhece, talvez nunca mais a veja na vida, ou mesmo que seja alguém conhecido, que é a capacidade de tirar o seu bom humor, seu otimismo, ou a sua motivação? Esteja atento para essas armadilhas da comunicação e previna-se. Conheço uma frase de um filme de treinamento chamado "O Homem Milagre", que diz o seguinte: "SNIOP", ou seja: "Salve-se das Nefastas Influências de Outras Pessoas". De qualquer modo é importante que você mesmo mantenha o devido controle emocional e saiba proteger-se dessas negatividades (CURVELLO, 2001).

\section{g) Foco de Mudanças}

Você não pode mudar as atitudes e comportamentos de outras pessoas. Assuma! Você é o responsável apenas por aquilo que está ao seu alcance e pelas mudanças que pode proporcionar a você mesmo (CURVELLO, 2001). 


\section{h) Motivação e Auto-estima}

Pode-se considerar como um dos aspectos mais importantes da comunicabilidade de uma pessoa, a energia que flui sutilmente através da sua voz e do seu corpo, das palavras e da sua postura, dos gestos e do olhar (SANTOS, 1965). É a expressão do seu otimismo ou pessimismo, da agressividade ou suavidade, do nível da sua auto-estima. É a comunicação invisível mas presente, percebida pelos sentidos. Quão agradável é a energia que flui de pessoas otimistas, bem humoradas, felizes, que diante das adversidades da vida encontram desafios que serão superados (BROCKA, 1995).

Para concluir, cabe ressaltar a sutileza da comunicação das pessoas que tem bondade no coração, a gentileza nos gestos, beleza e doçura nas palavras. "Sensualidade, alinhamento e graça permeiam seus movimentos. Uma nobreza natural flui silenciosa e discretamente em suas ações; há uma segurança pessoal apoiada na humildade; uma reverência, um senso de humor mesclado com a consciência do sagrado". Essas são as pessoas que fazem mais do que se comunicar, irradiam luz e brilho pessoal.

\subsection{COMUNICAÇÃO INTERPESSOAL: FUNDAMENTAL PARA HOTELARIA}

Ao estudar e desenvolver ferramentas para influenciar o comportamento das pessoas em processos de mudanças ou de re-estruturação, muitas vezes questionamos as pessoas e pensamos:

"Poxa, não esperava este comportamento reativo de fulano", ou

"Grande parte dos problemas neste processo está em fulano"

O fulano, quase sempre é uma pessoa com um comportamento, até então, diferente da conduta adotada. É como se não fosse previsível, em determinadas pessoas, comportamentos dissonantes. Neste momento percebemos que a capacidade de comunicação interpessoal é o ponto chave e de maior importância, nos relacionamentos entre as pessoas numa equipe. Os 
conflitos afloram entre os membros de um grupo, simplesmente pelo convívio do dia -a- dia corporativo.

Como resistir a tentação do tendencialismo, de adotar uma visão segregando as partes em dois status: Simpatia com uma parte e antipatia/ repugnância da outra parte (oposta).

Neste momento, vivemos o $\mathrm{X}$ da questão: Como resistir a estes esteriótipos, tão comum e cotidianamente vivido nas organizações ou em qualquer trabalho que é executado por uma equipe.

Esta tarefa, para o líder é difícil, mas não impossível! Precisamos entender que a idéia comunicada está relacionada com o grau de desenvolvimento do emissor e receptor. Porém, o contexto será único: As pessoas são diferentes e cada uma vive a sua diferença existencial em constante exposição com outras pessoas.

Para Brocka (1995, p. 39): "a percepção social é o entendimento e sentimento que as pessoas fazem, uma das outras". Funciona como um motor de partida, neste momento, qualquer atitude decorrente de uma análise superficial dos fatos, pode ser o propulsor de uma máquina rotuladora, e deve então, ser rapidamente eliminada.

Assim, o clima organizacional de excelência é aquele que não está sulcado por pessoas com conceitos pré-definidos. Portanto, a capacidade de relacionamento interpessoal torna-se um fator crítico de sucesso no processo de qualquer sistema de informação.

Precisamos incentivar as pessoas a atuarem em uma equipe, com uma postura pró-ativa e de empatia. Só assim, vamos eliminar as sub-culturas. Precisamos baixar as baias/divisórias em nossas organizações, e desenvolver em todos os colaboradores, a capacidade de relacionamento aberto, transparente. As baias/divisórias servem como casulo, cada qual, possui um líder. Num piscar de olhos, os casulos se fecham nas suas verdades.

Neste momento, o profissional de Recursos Humanos pode usar a percepção social como uma ferramenta eficaz na solução de conflitos. Principalmente pelos fatores ambientais da situação propriamente dita.

Quando se quebram as baias, a sensação de desconforto é muito grande. Existem relatos de ser comparado com a sensação da nudez, a quebra das baias. Torna-se necessário desenvolver simultaneamente a percepção social: 
A impressão a respeito dos outros! Isto deverá ser trabalhado pela área de Recursos Humanos, que neste caso agirá como mediador (KUBO, 2001).

Assim, podemos afirmar que o clima organizacional afeta 0 comportamento individual e conseqüentemente a equipe como um todo. Portanto, precisamos agir dentro dos limites de nossa capacidade de atuação, pois estamos entrando numa zona de conflito. A percepção social é influenciada por elementos distintos, vejamos:

*Esteriótipos - Distorção na percepção.

*Halo Effect - Generalizações, onde a impressão pré-formatada influenciará o julgamento.

*Projeção - Postura defensiva, criando padrões inconscientes.

*Defesa Perceptual - Distorção dos dados e eliminação das inconsistências (Dissonância cognitiva) (LITTLEJOHN, 1982; ROBBINS, 1987).

Em hotelaria, precisamos estar preparados para desenvolver em nossos colaboradores a capacidade da boa comunicação interpessoal. Isto tornase imprescindível ao bom andamento da organização, pois as pessoas exercem influência no clima organizacional e este é suscetível e sensível as vibrações e percepções das pessoas.

Em gestão estratégica de pessoas, a administração da comunicação entre as pessoas, é fator decisivo: Se inconscientes, torna-se a marca amarga do fracasso organizacional. Se consistentes, a boa comunicação entre as pessoas e organizações reflete no sucesso organizacional, e passa a ser $\mathrm{o} X$ da questão! (CURVELLO, 2001).

\subsection{HABILIDADES DA COMUNICAÇÃO INTERPESSOAL PARA HOTELARIA}

As Habilidades de Comunicação Interpessoal ( $\mathrm{HCls}$ ) são o conjunto de habilidades que permitem a comunicação entre duas pessoas. Através do aprimoramento das mesmas é que se consegue uma comunicação profissional mais eficiente. As $\mathrm{HCls}$ são desenvolvidas por meio de técnicas que permitem a 
formação de indivíduos com performance acima da média no processo de comunicação. Para cada tipo de contato existe a necessidade de adequação das técnicas que serão utilizadas (RABAÇA; BARBOSA, 1998).

Para Rabaça e Barbosa (1998, p. 60) é:

Através do aprimoramento das $\mathrm{HCls}$ podemos aperfeiçoar a capacidade de ouvir (ato de entender o que alguém quer nos dizer) em contraposição ao ato de escutar (ato mecânico de perceber os sons).

O que muito pode auxiliar na hotelaria, já que é um ramo de atividade dependente do relacionamento humano. Relacionamento esse dependente das condições pessoais dos colaboradores e de toda a estrutura da equipe componente de determinada empresa.

O desenvolvimento das HCls, conforme Ferreira et al (1996) pode abranger qualquer um dos tópicos a seguir:

\section{a) Etiqueta ao telefone}

Desenvolver a forma mais efetiva de comunicação. . Tratando cordialmente o cliente que está no outro lado da linha telefônica, com tom de voz plausível e pausado. Explicando calmamente o texto que se quer passar e prestando atenção as indagações do cliente, não deixando nenhuma pergunta sem resposta.

\section{b) Construção de empatia com o interlocutor}

Aprimorar a capacidade de se envolver mais com a realidade do interlocutor e, desta forma, atender melhor. Não simplesmente pensar no atendimento como forma de venda de um produto ou serviço, mas transparecer que o principal objetivo é o de satisfazer a realização de um desejo, não somente o repasse de custos, mas que o seu intuito é o de solucionar os problemas apresentados pelo interlocutor.

\section{c) Controle da conversa}

Aumentar a objetividade da conversa e, assim, a produtividade das chamadas. Ao atender, deve-se procurar brevidade e objetividade, para que o interlocutor não tenha que deter-se em explicações e discussões que não fazem 
parte do intuito principal da ligação, que é o de um atendimento e resolução de seu problema inicial.

\section{d) Ouvir em contraposição a escutar}

Aperfeiçoar a capacidade de ouvir (ato de entender o que alguém quer nos dizer) em contraposição ao ato de escutar (ato mecânico de perceber os sons). Ouvir e entender o que o interlocutor diz, é fundamental para o sucesso no atendimento de qualidade e excelência na prestação de um serviço com eficiência e qualidade. Ouvir, pode significar a satisfação plena do interlocutor.

\section{e) Comunicação escrita}

Desenvolver a habilidade de escrever de forma simples, clara e objetiva. Não somente ouvir e falar, mas comunicar-se por meio da escrita é fundamental, principalmente quando se anota recados, repasse de informações, números telefônicos e endereços que devem chegar até os clientes. Não apenas a forma gramatical deve ser observada, mas também a apresentação do documento e ortografia.

\section{f) Métodos de venda}

Introduzir métodos para a realização de vendas. As abordagens devem ser relacionadas com o tipo de cliente, e não apenas seguir um roteiro prédeterminado e fixo.

\section{g) Uso da voz para transmitir uma atitude positiva}

Enriquecer a experiência da comunicação telefônica. Transmitir mensagens positivas e respostas afirmativas, não dando margem a dualismo, ou mesmo entendimento errôneo sobre aquele ponto que se deseja falar. Ser honesto, objetivo e claro quando se responde a perguntas é ponto-chave para se ter um atendimento de qualidade.

\section{h) Atenuação de sotaques regionais}

Minimizar rejeições por parte de alguns clientes. Não reforçar e nem se desleixado quando se dirigir a pessoas de diferentes regiões do país, ter 
atenção para não desprezar o seu próprio sotaque e nem "imitar" o das pessoas com as quais nos relacionamos. Este tópico é melhor explicitado no seguinte.

\section{i) Determinação de um canal eficiente de comunicação}

Identificação do estilo de comunicação preferido (próprio e do interlocutor). Através de uma metodologia de classificação de estilos, é possível o estabelecimento de um canal mais eficiente de comunicação interpessoal. Entendendo os termos e buscando satisfazer o interlocutor dentro de seus padrões de conduta de comunicação, o repasse de informações será mais eficiente e eficaz.

\section{j) Tratamento de clientes difíceis}

Permitir a manutenção ou captura de clientes que, de outra forma, seriam perdidos. Mesmo o cliente tendo razão em suas alegações, é importante deixar explícito que suas queixas serão averiguadas e que a equipe de trabalho tem sua razão também. Atender bem é um objetivo claro e certo de toda empresa, contudo nem sempre a forma como se busca almejar este objetivo é plenamente agradável e compreendida por todos.

\section{k) Retenção de clientes}

Conhecer técnicas de negociação para a retenção de clientes. Negociar é a palavra-chave, tendo em mente que mesmo aqueles clientes que não cumpriram a sua parte no relacionamento anteriormente tido, podem ser, em outra oportunidade, excelentes colaboradores e divulgadores de nossa empresa. Todos devem ser tratados de forma igualitária e justa.

Dentro da hotelaria, estes pontos são fundamentais para o pleno estabelecimento de metas que possam visar a satisfação total dos clientes, desde o atendimento inicial, feito por telefone, até a saída do cliente de dentro do hotel.

Os recursos apresentados aqui, estão entrelaçados, de maneira que quando um deles não for bem executado, comprometerá toda a cadeia, influenciando no demais. Por isso mesmo é imperioso ter-se em mente que todos os pontos discutidos, devem ser entendido separadamente, mas não podem ser encarados de forma distinta entre um e outro, ou seja, são partes que formam um 
todo: o hotel e a plena satisfação de seus clientes. Aliando a isso, as habilidade de comunicação interpessoal, vemos que este objetivo é possivelmente alcançado.

\section{CAPÍTULO III}

\subsection{TURISMO NA ERA DA GLOBALIZAÇÃO}

A globalização é um fenômeno tão importante quanto a Revolução Industrial e a Reorganização Capitalista da década de trinta. É a integração econômica e tecnológica dos países. A globalização da economia não é um processo ideológico. É um movimento de transformação social e de produção que vai permitir melhoria da qualidade de vida do cidadão e domínio cada vez maior das potencialidades naturais.

Os efeitos da globalização na atividade de turismo no Brasil, contribuiu para atrair capital para o setor produtivo brasileiro e a inserção das empresas e produtos no mercado financeiro internacional. Uma das maiores contribuições que o governo pode dar nesse sentido é garantir condições de competitividade (diminuição da carga tributária, qualificação de mão de obra, etc.) que permitam à empresa nacional ser competitiva sem necessidades de subsídios expressivos.

Os países emergentes terão que entender a lógica e aprender a barganhar os investimentos diretos em seu território. A globalização e a abertura das economias emergentes são inevitáveis e serão garantia adicional para a própria estabilidade monetária, já que pressionam para baixo os preços internos (MAFFESOLI, 2001).

É imprescindível que o empresário do setor de turismo realize seus negócios tendo em vista esta nova realidade na era da globalização da economia, passe a priorizar investimentos tanto em tecnologia como em treinamento de mão 
de obra e também reorganiza sua empresa através da implantação de modernas técnicas de gerenciamento. Este conjunto de medidas que o empresário deverá tomar será importante não só para a sua sobrevivência no mercado diante da maior competitividade que a globalização traz, mas também como forma de reduzir seus custos e proporcionar um produto final com maior qualidade a preços menores.

\subsection{ADMINISTRAÇÃO HOTELEIRA}

Um dos pontos essenciais para o sucesso de uma atividade turística é a disponibilidade de meios de hospedagem e isso data de longo tempo.

O foco principal da administração hoteleira tem variado ao longo do tempo de acordo com o momento histórico vivenciado, caracterizando várias fases distintas. No século XVII, a atenção estava voltada para a produção. Tínhamos a Era da Produção, inicialmente voltada para a produção para a subsistência, onde o cerne da preocupação é a produção para o consumo próprio, evoluindo já no século XVIII para a produção sob encomenda, onde os clientes ditavam as características dos produtos que iriam adquirir, produção essa que pode ser interpretada como realizada de forma artesanal, gerando por conseguinte um sub-aproveitamento dos meios de produção disponíveis (CURVELLO, 2001).

Com o passar do tempo, isso acabou levando os produtores a se arriscarem a fabricar bens que julgavam ter maior aceitação por parte dos clientes de modo a utilizar melhor sua capacidade e a dos meios de produção existentes. Nesse momento o importante era produzir.

A partir de meados do século $X X$, chegamos à era do produto, na qual o foco da atenção da empresa continua a ser interno. São direcionados os esforços e despendidos os recursos no intuito da melhoria dos produtos da empresa, sem, no entanto, observar se esses produtos melhorados iam ao encontro das necessidades e desejos dos clientes.

Nessa mesma época, a partir da década de 1970, surge naturalmente a preocupação com o cliente. As organizações, conseqüentemente, 
passam a apresentar um foco no marketing, transformando as vendas em uma das funções do marketing da empresa.

\subsection{BREVE HISTÓRIA DOS MEIOS DE HOSPEDAGEM}

A Hotelaria é uma das atividades mais antigas. Desde, aproximadamente, IV a.C., existia-se a necessidade de serviços que oferecessem alimentação e abrigo, principalmente, por causa das relações comerciais que tornavam as viagens algo comum e freqüente.

Os primeiros meios de hospedagem que foram se desenvolvendo não tinham a característica de uma atividade comercial específica. As hospedagens, no início, eram realizadas em casas de famílias ou, no caso dos nobres, em palácios, sem que houvesse pagamento algum. Com a evolução da sociedade, no entanto, tornou-se necessário o surgimento das hospedarias que nada mais era do que casas aonde se abrigavam hóspedes e peregrinos mediante remuneração e cuja fama "dependia do luxo e dos serviços cerimoniais oferecidos a seus clientes". (DUARTE, 1996, p. 09 apud FERREIRA, 1996, p. 23).

Em 1406, surgiu na França, o primeiro registro para hóspedes que se tem notícia. Foi nos Estados Unidos que surgiu o primeiro edifício especialmente para funcionar como hotel, o City Hotel em Nova York. Em seguida foi em Boston (EUA) o primeiro hotel de luxo nas Américas, o Tremont House.

Com o passar dos tempos, as antigas hospedagens foram cedendo seus lugares para hotéis mais sofisticados e planejados . "Foi então (fim do século XIX) que homens como Cezar Ritz procuraram dar forma e organização aos hotéis" (CASTELLI, 1992, p. 21 apud LOVELOCK e WRIGHT, 2001, p. 89). Esse suíço inovou o hotel oferecendo aos seus clientes banheiro privativo e uniformizando os empregados para melhorar a imagem receptiva do estabelecimento.

Com a Revolução Industrial e o avanço tecnológico nos meios de transporte, o setor hoteleiro emergiu de maneira considerável, alterando a estrutura dos hotéis, modificando os métodos de atendimento que passaram a voltar-se para o proporcionamento de conforto e qualidade dos serviços de acordo 
com o desejo dos hóspedes, bem como, exigindo, do profissional hoteleiro, um conhecimento mais profundo e adequado aos serviços prestados.

No Brasil, a evolução hoteleira ocorreu principalmente após a Segunda Guerra Mundial devido ao surto industrial da década de 60. No entanto, os historiadores registram no início do século XVII o aparecimento do primeiro hoteleiro oficial de São Paulo (Marcos Lopes), seguido poucos anos mais tarde pela cigana Francisca Rodrigues, que montava sua estalagem e talvez o primeiro restaurante da gastronômica cidade de São Paulo, que anunciava, entre outras coisas, carne, bijou, e farinha, segundo Duarte (FERREIRA, 1996). Porém, "é possível citar como um dos primeiros alojamentos a Casa de Anchieta, em São Paulo, no século XVI, que servia de abrigo aos religiosos que para cá vinham em nome da Companhia de Jesus". (LOVELOCK e WRIGHT, 2001, p. 89).

No início dos anos 70, começou a surgir um novo processo de modificação de serviços nos hotéis, a automação, decorrente do desenvolvimento da informática, sempre visando dar um maior atendimento aos clientes/hóspedes. Surge então uma pergunta: Será possível algum dia um hotel totalmente computadorizado, sem funcionários? Segundo alguns autores como Casteli, Zanelli e Farah não, porque os hóspedes sempre alem do conforto, pronto atendimento, etc., sentem falta do calor humano e isto o computador não tem a oferecer.

No Brasil, ainda hoje, o nível de automação é relativamente baixo, principalmente porque a mão de obra é abundante (se bem pouco qualificada e barata).

\subsubsection{Tipo de hotéis}

Os tipos de hotéis existentes são variados, no entanto, será citado adiante os três mais comuns, de acordo com a freqüência de utilização e com as tendências de mercado (SERSON, 1999 apud LOVELOCK e WRIGHT, 2001). 


\section{a) Hotel e Meio Ambiente}

Cada vez mais, as pessoas buscam aventurar-se nas correntezas de um rio, conhecer as belezas naturais de uma região e livrar-se do seu lado urbano fugindo para a selva, sem, no entanto, porem suas vidas em risco. Conseqüentemente, um maior número de estabelecimentos hoteleiros visam oferecer serviços de lazer que proporcionem aos hóspedes uma interação com o meio ambiente, através da oferta de atividades relacionadas à ecologia.

A natureza e o turismo, simultaneamente, a hotelaria sempre estiveram diretamente relacionados, já que "os recursos naturais constituem um dos principais fatores motivadores dos fluxos turísticos promovidos pela atratividade dos lugares ou espaços geográficos, tendo na paisagem uma das suas representações." (CORIOLANO, 1997, p. 11).

A exploração do meio ambiente pelos estabelecimentos, entretanto, deve ser realizada de maneira ecológica objetivando a preservação e não apenas visando o lado econômico que acaba acarretando uma degradação da paisagem natural, devido a modificação exercida, e gerando futuros prejuízos tanto para a sociedade quanto para a própria empresa hoteleira.

As empresas turísticas, em destaque os hotéis, precisam conscientizar-se da importância do meio ambiente à garantia de sua sobrevivência, não só pelo fato de ser um fator ligado à obtenção de recursos, mas, também, por ser uma tendência que vem tomando conta de toda a humanidade.

\section{b) Hotel Convencional}

Alguns estudiosos definiam o hotel como sendo uma unidade econômica que tinha por objetivo preparar e prestar bens e serviços ao turismo, porém "essa definição é abrangente, pois nem todas as empresas (unidades econômicas) que fazem parte da oferta turística prestam seus serviços 
exclusivamente ao turismo". (CASTELLI, 1992, p. 18 apud LOVELOCK e WRIGHT, 2001, p. 36).

Um hotel pode ser classificado com base no padrão da maioria dos seus usuários, sendo o Hotel Convencional, verificando-se a classificação estabelecida por Serson (1999, p. 42 apud LOVELOCK e WRIGHT, 2001, p. 52), enquadrado na categoria de Hotéis de Negócios que "destinam-se basicamente para pessoas de negócios que, no mais das vezes, os usam para permanência curtas. Estão, em geral, localizados nos centros das cidades ou próximos a algum centro comercial, industrial ou financeiro."

Muitas empresas brasileiras se dedicam exclusivamente a viagens de negócios, devido ao lucro adquirido ser mais certo, como é o caso da maioria das redes hoteleiras do mundo.

Através de uma simples observação, percebe-se que o Hotel Convencional tem por objetivo principal vender suas diárias e complementos hoteleiros (alimentos e bebidas, lavanderia, entre outros) sem, na maioria das vezes, oferecer entretenimentos do tipo quadra de esportes, passeios turísticos, teatro, entre outros meios de diversão que normalmente são fornecidos por hotéis de lazer.

Além das diárias, outra fonte de renda, porem em segundo plano, comumente explorada por esse tipo de hotel, são os centros de convenções, visando a realização periódica de eventos, reuniões empresariais e congressos para, assim, divulgar indiretamente o estabelecimento e atingir um aumento na quantidade de hospedagens demandadas.

Com está rápida análise, conclui-se que o Hotel Convencional visa oferecer, de maneira indiscriminada, alojamentos a executivos e turistas que permanecem em curto espaço de tempo no local visitado e que desejam apenas usufruir de um local para descanso (pernoitar) e alimentação que sirva de apoio à garantia de seu bem-estar. 


\section{c) Hotel Resort}

Os hotéis, de acordo com Serson (1999) podem ser classificados em Hotéis de Negócios, Estâncias Turísticas, Hotéis Residenciais e Hotéis de "Beira de Estrada", sendo o Resort, observando-se as características de cada um, relacionado às Estâncias Turísticas, pois orientam-se principalmente para pessoas em férias; localizam-se em pontos de interesse turístico, como praia, montanha ou parque temáticos, e apresentam ainda locais de recreação, como quadras de esporte e piscina.

O Resort é uma opção bastante atraente tanto para os negócios quanto para o turismo, pois atende a diversas tendências e é praticamente uma garantia de sucesso, para os empresários que investem nesse setor, e conforto, para os clientes que usufruem da qualidade dos serviços.

Muitos Resorts permitem ao hóspede entrar em contato com a natureza, acobertado pela garantia de segurança e um serviço excelente, repleto de atividades como caminhadas ecológicas, passeios aquáticos, esportes em geral, entre outros entretenimentos. Com isso, essa categoria de hotel deixa de ser um simples local de hospedagem para tornar-se o próprio destino do viajante. (KUBO, 2001).

"Os resorts são uma feliz combinação de lugares muito bonitos, boas instalações, atendimento de primeira linha e uma série de opções de lazer, de forma a oferecer ao hóspede uma experiência completa", (CIAFFONE, 2000, p. 03).

E atrair aqueles que visam fugir da incômoda agitação urbana, porém protegidos pelo apoio de uma cidade localizada a poucos metros do estabelecimento, como é o caso do megaresort Cabo de Sauípe, composto de cinco hotéis de alto padrão, seis pousadas e uma infra estrutura de entretenimento e lazer projetada para dar vida ao próprio complexo, fazendo-o funcionar como uma comunidade turística.

A expansão do Resort no Brasil, deve-se principalmente à capacidade de atrair turistas estrangeiros que desejam conhecer as belezas brasileiras sem ter que lidar com as dificuldades da língua portuguesa, já que os serviços facilitam a comunicação para eles, e os perigos das grandes cidades, 
porém o número de brasileiros a utilizarem essa categoria de estabelecimento, também, tem evoluído devido a desvalorização do real frente ao dólar, que tornou as viagens internacionais mais onerosas e menos atraentes.

Com essa explanação verifica-se que o Resort é um estabelecimento hoteleiro voltado ao lazer localizado próximo a centros urbanos que objetivam oferecer uma alternativa de descanso e diversão àqueles que procuram passar um período de relaxamento junto a familiares ou amigos e desejam retornar à rotina e ao trabalho ao término de tudo que the propôs um bem-estar momentâneo e diferente.

\section{d) Pousadas}

Os resorts são uma excelente opção de mercado, porem serão, em pouco tempo, ultrapassados pelas Pousadas que oferecem um serviço semelhante com a vantagem de localizarem-se em lugares extraordinários. Com base na CNTUR, Pousada é um:

\footnotetext{
Estabelecimento comercial de hospedagem, instalado total ou parcialmente em edifício de valor histórico ou de significação regional, ou local reconhecido pelo poder publico, e que alugue, para ocupação temporária, aposentos mobiliados com serviços de alimentação parciais, oferecendo ainda outros serviços complementares da industria hoteleira. (CASTELLI, 1992, p. 38 apud LOVELOCK e WRIGHT, 2001, p. 42).
}

No entanto, a tendência do mercado a faz concentrar-se em lugares tranqüilos, como ilhas e fazendas (reconhecidos pelo poder público), com pouca gente e atendimento personalizado, ideal para aquelas pessoas que necessitam ou desejam desligar-se da vida moderna.

Isso não significa dizer que os resorts não proporcionam essa fuga, mas, por situarem-se próximos aos centros urbanos, causam uma agitação que impossibilita o sossego daqueles que o almejam.

Um exemplo que encaixa-se perfeitamente a essa atualidade e nos conscientiza da sua relevância para o futuro dos negócios voltados ao lazer, é a 
Pousada da família Sehn, que alia ecologia e lazer com luxo e conforto dos melhores hotéis. Localizada na ilha do Papagaio, no município catarinense de Palhoça, $30 \mathrm{Km}$ ao sul de Florianópolis, a Pousada, por mais que localize-se próximo a um centro urbano, tem côo meio de acesso, apenas barcos ou helicópteros, dificultando, assim, o tumultuo e o excesso de pessoas.

Renato Sehn, o criador da pousada, buscou formar:

Aquilo que imagina ser um dos negócios mais promissores do turismo nos próximos anos: pequenos hotéis charmosos, localizados em lugares fantásticos, isolados da vida moderna e conduzidos pessoalmente pelos donos. (SENGE, 1996, p. 51).

Outro caso que demonstra essa tendência à fuga é o exemplo da associação de Roteiros de Charme, entidade que reúne 30 pequenos hotéis e tem por objetivo fornecer "todo o conforto com o menor impacto ambiental possível", realizando, para isso, uma meta que visa extinguir até o secador de cabelos em no máximo dois anos e possuir uma fonte de energia solar, proporcionando aos seus consumidores o prazer de viver, temporariamente, de maneira rústica.

Os investimentos efetuados nesta categoria de estabelecimento hoteleiro deverá gerar um faturamento fantástico aos empresários que dedicaremse a esse ramo de atividade; e a razão para isso deve-se ao fato de o lazer voltado ao natural não ser apenas uma febre que vem e passa, e sim uma tendência duradoura e essencial à própria sobrevivência do homem. 


\section{CONSIDERAÇÕES FINAIS}

Promover a comunicação e otimizar relacionamentos, ao contrário do que podemos imaginar, está ao alcance de todos, independente do nível social, educacional, cultural ou da história de vida. Somos o único ser vivo capaz de repensarmos nossas ações e planejarmos nosso futuro, pois temos ao nosso dispor a memória com a qual podemos aprender e reaprender.

Basta que estejamos com predisposição para a mudança abrindo as portas do extenso caminho, porém gratificante.

Para tanto além da introspecção reflexiva, o indivíduo deve conhecer o universo daquele com o qual está se comunicando. Usar a empatia, ou seja, saber se colocar no lugar do outro para poder prever o por quê de ele agir desta ou daquela forma, entendendo que ninguém é dono da verdade. Somos influenciados pelos nossos filtros a ver o mundo de acordo com o que julgamos certo, porém, o certo e o errado são conceitos por demais subjetivos, cada um defende o seu lado conforme lhe convier e de acordo com a sua percepção de mundo.

O profissional da hotelaria, deve estar capacitado a atuar em diferentes funções dentro de sua atividade profissional, ao mesmo tempo em que deve estar antenado com as diferentes ferramentas de trabalho que possam auxilia-lo em seu cotidiano profissional.

A atualização dos profissionais da hotelaria deve ser uma constante, a participação em feiras, palestras, workshops, cursos, deve fazer parte de seu ambiente de trabalho, sendo compromisso da empresa (hotel) favorecer 0 enriquecimento intelectual de sua equipe. O mercado hoje não exige apenas os melhores profissionais, mas aqueles que estão melhor preparados para enfrentar a rotina e as adversidades que surgem, fruto das modificações impostas pela clientela e público usuários dos serviços como um todo.

A comunicação, vista aqui, desde de seus princípios básicos, é fator primordial para a excelente qualificação do corpo de funcionários e equipe de trabalho como um todo, de maneira que as habilidades de comunicação 
interpessoal devem ser trabalhadas visando o melhoramento do relacionamento interpessoal dos que compõem a equipe de trabalho.

O indivíduo com as estratégias da comunicação interpessoal adquire a habilidade e o discernimento de percepção da realidade que o cerca, indo além do que o seu mapa representa, desta forma ampliando sua visão de mundo.

Neste sentido, foi possível confirmar que homem é cem por cento (100\%) responsável pelo seu destino. Tendo em vista que, o sucesso de cada um depende da qualidade e harmonia dos relacionamentos estabelecidos em todas as esferas de sua vida e principalmente o que tem consigo próprio.

A comunicação interpessoal aponta num contexto mais amplo do relacionar-se o imprescindível comprometimento do indivíduo em comunicar-se com um poder maior. Pois na hierarquia dos níveis neurológicos, a espiritualidade nos leva a uma reflexão que nos conduz à comunicação com o SER, nos levando a interagir com as leis até mesmo do universo.

Embora o relacionamento e a comunicação estejam diretamente interligados, podendo até ser afirmado que, da eficácia de um depende o sucesso do outro,ainda assim, torna-se pertinente lembrarmos que a comunicação interpessoal, tem muito para oferecer no sentido de melhorar os processos de comunicação.

Se o indivíduo estiver interessado em buscar uma ampliação das suas percepções, não é diferente a intenção dos fundamentos da comunicação interpessoal, que está pautado em inúmeros recursos para facilitar a vida do ser humano. Assim sendo ferramenta indispensável para a consolidação do mercado hoteleiro, favorecendo seu enriquecimento cultural, social e econômico como um todo. 


\section{REFERÊNCIAS}

ÁVILA, F. B. de S.J. Pequena Enciclopédia de Moral e Civismo. Rio de Janeiro: M.E.C., 1967.

BANDLER, R.; GLINDER, J. Resignificando: Programação neurolingüística e transformação do significado. 4. ed. São Paulo: Summus, 1986.

BATISTA, A. Tempo, Comunicação e Liberdade. Rio de Janeiro: Civilização Brasileira, 1971.

BAUM, W. M. Compreender o Behaviorismo: Ciência, Comportamento e Cultura. Porto Alegre: Artes Médicas, 1999.

BERGER, Peter L.; LUCKMANN, Thomas. A construção social da realidade. 13. ed. Petrópolis: Vozes, 1996.

BERLO, D. K. O Processo da Comunicação: Introdução á Teoria e á Prática. São Paulo: Martins Fontes, 1999.

BOTOMÉ, S. P. Sobre a noção de comportamento. In: Filosofia: diálogo de horizontes. Heloísa Pedroso de Moraes Feltes e Urbano Ziles. Porto Alegre: EDIPUCRS, 2001.

BOWDITCH, J. L. e BUONO, A. F. Elementos de Comportamento Organizacional. São Paulo: Pioneira, 1992.

BROCKA, Bruce. Gerenciamento da qualidade. São Paulo: Makron Books, 1995.

CURVELLO, J. J. Autopoiese, Sistema e Identidade: a comunicação organizacional e a construção do sentido em um ambiente de flexibilização nas relações de trabalho. Tese de doutorado em Ciências da Comunicação da ECA/USP. São Paulo, abril de 2001.

DEFLEUR, M. \& BALL-ROKEACH, S. Teorias da comunicação de massa. Rio de Janeiro: Zahar, 1997.

FERREIRA, J.M. et al. Psicossociologia das Organizações. Portugal: McGrawHill, 1996.

KUBO, O. M.; BOTOMÉ, S. P. Ensino-aprendizagem: uma interação entre dois processos comportamentais. In: Revista Interação. v 5, janeiro/dezembro, p. 133169. Departamento de Psicologia da UFPR. Curitiba, 2001.

LITTLEJOHN, S. W. Fundamentos teóricos da comunicação humana. Rio de Janeiro: Zahar, 1982. 
LOVELOCK, Christopher e WRIGHT, Lauren. Serviços: Marketing e Gestão. São Paulo: saraiva, 2001.

MAFFESOLI, Michel. A contemplação do mundo. Porto Alegre: Artes e Ofícios, 1995.

O'CONNOR, J.; SEYMOUR, J. Introdução à programação Neurolingüística: como entender e influenciar as pessoas. 3. ed. São Paulo: Summus, 1995.

RABAÇA, C.A; BARBOSA, G. Dicionário de Comunicação. São Paulo: Ática, 1998.

ROBBINS, A. Poder sem limites: o caminho do sucesso pessoal pela Programação Neurolingüística. 40. ed. São Paulo: Best seller, 1987.

RÜDIGER, F. R. Comunicação e Teoria Social Moderna. Porto Alegre: Fênix, 1995.

SANTOS, M. F. dos. Dicionário de Filosofia e Ciências Culturais. 3. ed. São Paulo: Matese, 1965.

SENGE, P. A Quinta disciplina. Rio de Janeiro: Qualitymark, 1996.

SCHUTZ, Alfred. Fenomenologia e relações sociais. Rio de Janeiro: Zahar, 1979.

SKINNER, B. F. Ciência e Comportamento Humano. São Paulo: Martins Fontes, 1981.

VELLASCO, Ana M. De Moraes -Centro de Turismo Da Unb - Manual de Orientação para Produção de Textos Acadêmicos; Brasília : Unb, 2003 (www.unb.br/cet). 